\title{
PENGARUH JUMLAH ZAKAT PRODUKTIF, UMUR PRODUKTIF, JUMLAH TANGGUNGAN, DAN PENGAWASAN TERHADAP PRODUKTIVITAS USAHA (SURVEY PADA MUSTAHIK KABUPATEN PIDIE)
}

\author{
Assafriani $^{1}$, Meutia Fitri ${ }^{* 2}$ \\ ${ }^{1,2}$ Program Studi Akuntansi Fakultas Ekonomi dan Bisnis Universitas Syiah Kuala \\ e-mail: assafriani@gmail.com¹,meutia.fitri@unsyiah.ac.id² \\ * Corresponding Author
}

\begin{abstract}
Abstrak
This study aims to determine the influence of productive zakat amount, productive age, dependents of mustahik, and controll towards productivity of mustahik reaching. This research is conducted by taking samples of mustahik who earn productive zakat from Baitul Mal Pidie and chosen sample for 53 mustahik. The data and information collection used in this study was documentation technique. The data used was the secondary data which directly collected from Baitul Mal Pidie. The testing of independent variable influence toward the dependent variabel used this study was multiple regression model by using SPSS 23.The result of the reseach shows that simultaneously productive zakat amount,productive age, dependents of mustahik, and control have an effect productivity of mustahik reaching. However partially only variable productive zakat amount and controll that effect the productivity of mustahik reaching. Productive age and dependents of mustahik are not affect the productivity of mustahik reaching.
\end{abstract}

Keywords: Productive Zakat, Productive Age, Dependents of Mustahik, Controll, Productivity of Mustahik Reaching

\section{Pendahuluan}

Permasalahan yang sering dihadapi oleh negara berkembang yang salah satunya Indonesia, yaitu masalah ekonomi. Permasalahan ekonomi suatu negara dapat memberikan dampak negatif terhadap kehidupan sosial masyarakat diantaranya kemiskinan dan pengangguran sehingga menimbulkan terjadinya tindakan-tindakan kriminal. Untuk mengatasi permasalahan tersebut maka diperlukan suatu kebijakan yang dapat menanggulangi masalah kemiskinan (Salmawati:2018).

Kemiskinan bukanlah suatu perkara yang mudah untuk diselesaikan. Hal ini dikarenakan kemiskinan merupakan salah satu bentuk dari kekuasaaan Allah untuk mengetahui sejauh mana tingkat kepedulian hamba-Nya yang memiliki kekayaan lebih terhadap saudaranya yang berkekurangan. Islam memberikan gambaran umat muslim sebagai satu batang tubuh dimana setiap anggota dan bagiannya saling berkaitan. Oleh karenanya dalam lingkungan sosial Islam menekankan terciptanya hubungan saling tolong menolong. Menurut Qardawi (2011:49) zakat sangat berperan penting dalam penanggulangan kemiskinan.

Zakat biasanya didistribusikan dalam bentuk konsumtif, yaitu zakat yang pendistribusiannya bertujuan agar terpenuhinya kebutuhan konsumsi mustahik dalam kehidupan sehari-hari. Namun, belakangan ini zakat juga disalurkan dalam bentuk produktif. Zakat produktif adalah dana zakat yang dapat dikelola dan dikembangkan oleh mustahik sedemikian rupa sehingga mendatangkan manfaat dalam jangka waktu yang lama (Asnainu, 2008:64). Sistem zakat produktif yaitu berupa pinjaman bebas bunga yang diberikan badan pengelola zakat kepada mustahik dalam rangka menjalankan usaha.

Salah satu fungsi dari zakat yaitu untuk mensejahterakan masyarakat yang masih tergolong kurang mampu. Pemerintah berharap zakat dapat dijadikan sebagai salah satu solusi dalam mengurangi persentase kemiskinan. Kesejahteraan masyarakat dapat ditandai dengan meningkatnya produktivitas. Produktivitas merupakan salah satu unsur penting yang dapat mempengaruhi kemajuan dan kemunduran suatu usaha. Artinya, meningkatkan produktivitas sama halnya dengan meningkatkan kesejahteraan 
(Lestari et al., 2009). Produktivitas merupakan perbandingan antara keluaran (output) dengan masukan (input) (Busro, 2018:341). Secara sederhana produktivitas mustahik dapat diartikan sebagai total keseluruhan penghasilan yang diterima mustahik setelah menerima dan mengelola zakat produktif. Terdapat beberapa faktor yang mempengaruhi produktivitas usaha mustahik, diantaranya yaitu jumlah zakat produktif, umur produktif, jumlah tanggungan, dan pengawasan.

Alasan didistribusikannya zakat produktif diantaranya yaitu apabila mustahik berhasil melakukan pengelolaan dengan baik, zakat produktif dapat berlangsung dalam jangka panjang sehingga zakat produktif dianggap sebagai salah satu upaya yang sangat efektif untuk merubah status mustahik menjadi muzakki. Dengan kata lain, zakat produktif yang diberikan tersebut tidak langsung dihabiskan, tetapi dapat dijadikan sebagai modal mereka dalam mengembangkan usaha, dengan adanya usaha tersebut maka kebutuhan mereka dapat terpenuhi secara terusmenerus. Disisi lain, pendistribusian zakat dalam bentuk konsumtif dikhawatirkan akan membuat para mustahik tergantung terhadap dana zakat tersebut meskipun memang hak mereka.

Objek dalam penelitian ini adalah mustahik yang menerima zakat produktif dari Baitul Mal Pidie. Berdasarkan data BPS 2018, saat ini Aceh menjadi provinsi termiskin di Sumatera dengan jumlah penduduk miskin sebanyak 831 ribu jiwa (detik.news, 15 Januari 2019). Salah satu faktor yang menyebabkan terjadinya kemiskinan adalah karena rendahnya tingkat produksi dan kurang berkembangnya suatu usaha (Rusli, 2013). Adapun alasan memilih Baitul Mal Pidie sebagai objek penelitian yaitu dikarenakan pada tahun 2017 diantara 23 Kabupaten/Kota di Aceh, Pidie merupakan salah satu Kabupaten/Kota yang tingkat kemiskinannya mencapai $21,43 \%$, terjadi peningkatan dari sebelumnya 21,25\% di tahun 2016 (ModusAceh.co, 17 agustus 2018). Sebenarnya program zakat produktif yang dijalankan oleh Baitul Mal bertujuan untuk mengurangi tingkat kemiskinan. Dikarenakan zakat produktif dapat menjadikan mustahik menjadi lebih produktif. Namun pada kenyataannya tujuan tersebut masih belum tercapai. Permasalahan utama yang menyebabkan hal tersebut terdapat pada pihak internal dan eksternal lembaga pengelolaan zakat. Adapun permasalahan internal dalam menyelenggarakan program pemberdayaan melalui pendayagunaan zakat atau biasa disebut dengan zakat produktif adalah belum matangnya perencana program, kurangnya SDM pendamping yang handal,belum adanya alat ukur kebehasilan program. Selain permasalahan internal, terdapat juga permasalahan eksternal lembaga pengelolaan zakat yaitu lemahnya penataan sistematik kelembagaan, rendahnya jiwa kewirausahaan mustahik, dan mustahik tidak mengetahui aturan program zakat produktif (fitriani, 2016).

Berdasarkan uraian diatas, maka peneliti tertarik untuk melakukan penelitian tentang "Pengaruh Jumlah Zakat Produktif, Umur Produktif, Jumlah Tanggungan, dan pengawasan terhadap Produktivitas Usaha (Survey pada Mustahik Kabupaten Pidie)".

\section{Kerangka Teoritis Dan Pengembangan Hipotesis \\ Jumlah Zakat Produktif dan Produktivitas Usaha Mustahik}

Produktivitas mengandung makna secara filosofis dan definisi kerja. Secara filosofis, produktivitas diartikan sebagai pandangan hidup dan sikap mental yang terus menerus berupaya untuk meningkatkan mutu kehidupannya, bahwa kehidupan hari ini harus lebih baik dari kemarin dan keadaan besok harus lebih baik dari hari ini dan seterusnya (Soetrisno, 2009:101). Pandangan hidup yang seperti ini akan membuat manusia tidak pernah merasa puas sehingga terus menerus mengembangkan diri dan meningkatkan kemampuan dalam bekerja. Secara definisi kerja, produktivitas adalah perbandingan antara hasil yang dicapai (output) dengan total sumber daya (input) yang dipergunakan per satuan waktu. Definisi kerja ini memiliki cara atau metode pengukuran (Afrida, 2003:36). Produktivitas secara umum dapat diartikan sebagai perbandingan antara keluaran (output) dengan pemasukan (input) (Busro, 2018:341).

Menurut Harsanto (2013:59) salah satu faktor yang memberikan dampak terhadap produktivitas adalah modal. Modal merupakan faktor yang memiliki peranan penting dalam kegiatan produksi dan pengembangan usaha. Jumlah zakat produktif yang diberikan kepada mustahik akan digunakan sebagai 
modal usaha. Semakin besar jumlah zakat produktif yang diberikan, maka proporsi yang dihasilkan mustahik akan semakin besar pula sehingga mampu mempengaruhi produktivitas usaha. Penelitian Fajrin (2015) menyatakan bahwa secara individual variabel modal usaha mikro mempunyai dampak yang positif terhadap variabel keuntungan usaha mustahik secara signifikan. Semakin banyak usaha mikro, maka keuntungan usaha mikro yang dihasilkan juga semakin meningkat.

\section{Umur Produktif dan Produktivitas Usaha}

Sinungan (2003:56) menyebutkan salah satu faktor umum yang mempengaruhi produktivitas adalah manusia, yang meliputi keahlian dan umur. Umur sangat mempengaruhi keberhasilan suatu usaha, baik yang bersifat fisik maupun nonfisik. Pada umumnya, mustahik yang berumur tua mempunyai tenaga fisik yang lemah dan terbatas. Namun sebaliknya, mustahik yang berumur muda mempunyai tenaga fisik yang kuat. Akan tetapi umur yang produktif mempunyai batasan tertentu. Semakin bertambah umur produktif mustahik maka dianggap semakin produktif karena dianggap memiliki lebih banyak pengalaman dibandingkan dengan mustahik yang berumur muda kecuali mustahik yang sudah memasuki usia pensiun. Muda dan Arfan (2016) menyatakan bahwa variabel umur produktif mustahik secara parsial mempunyai dampak signifikan terhadap produktivitas usaha mustahik.

\section{Jumlah Tanggungan dan Produktivitas Usaha}

Tenaga kerja atau sumber daya manusia merupakan salah satu faktor yang yang memberikan dampak pada produktivitas (Harsanto, 2013:59), sedangkan produktivitas tenaga kerja itu sendiri menurut Simanjuntak (1998) dipengaruhi oleh jumlah tanggungan keluarga. Adapun tanggungan keluarga sangat dipengaruhi oleh jumlah anggota keluarga. Apabila jumlah anggota keluarga semakin besar, maka biaya hidup yang akan dikeluarkan juga akan semakin besar, sehingga hal ini dapat mempengaruhi produktivitas usaha mustahik. Himawan (2015) menyatakan bahwa beban tanggungan mempunyai dampak signifikan terhadap produktivitas tenaga kerja

\section{Pengawasan dan Produktivitas Usaha}

Harsanto (2013:59) menyebutkan bahwa salah satu faktor yang mempengaruhi produktivitas adalah manajemen. Adapun Suanaengsih (2009) mengatakan bahwa controling merupakan bagian dari manajemen, untuk melakukan penilaian, pengukuran, dan koreksi sehingga apapun yang dilakukan bawahan dapat diarahkan ke jalan yang benar. Semakin sering mustahik dikontrol maka kemungkinan terjadinya penyimpangan semakin kecil, dan tingkat kehatihatian mustahik dalam memanfaatkan dana zakat produktif lebih tinggi, begitu juga sebaliknya apabila pengontrolan mustahik jarang dilakukan maka kemungkinan mereka untuk memanfaatkan dana dengan semena-mena akan lebih tinggi. Sehingga mustahik yang sering dikontrol maka produktivitasnya lebih tinggi dibandingkan dengan mustahik yang jarang mendapatkan pengawasan. Pambudi (2013) menyatakan bahwa pengawasan berpengaruh signifikan terhadap pendapatan mustahik. Hal ini menandakan bahwa semakin tinggi tingkat pengawasan dari pengelola $\mathrm{BAZ}$ maka semakin tinggi pula penghasilannya.

\section{Hipotesis}

Berdasarkan kerangka pemikiran yang telah dijelaskan sebelumnya, maka hipotesis penelitian ini adalah sebagai berikut:

H1 : Jumlah zakat produktif, umur produktif, jumlah tanggungan dan pengawasan secara bersama-sama berpengaruh terhadap produktivitas usaha.

H2 : Jumlah zakat produktif berpengaruh terhadap produktivitas usaha.

H3 : Umur produktif berpengaruh terhadap produktivitas usaha.

H4 : Jumlah tanggungan berpengaruh terhadap produktivitas usaha.

H5 : Pengawasan berpengaruh terhadap produktivitas.

\section{Metode Penelitian \\ Desain Penelitian}

Desain penelitian merupakan kerangka kerja yang digunakan peneliti dalam melakukan penelitian dengan tujuan untuk mempermudah penelitiannya dikarenakan semua yang akan dilakukan peneliti telah direncanakan sebelumnya. Desain penelitian terdiri dari enam aspek yang terdiri dari tujuan studi, tingkat intervensi peneliti, situasi studi, strategi 
penelitian, unit analisis, dan horizon waktu studi (Sekaran, 2017:109). Aspek-aspek ini akan dijelaskan seperti berikut ini:

1. Tujuan Studi

Studi ini bertujuan untuk menguji pengaruh jumlah zakat produktif, umur produktif, jumlah tanggungan dan pengawasan terhadap produktivitas usaha.

2. Jenis penelitian

Jenis penelitian ini adalah Studi kausalitas. Studi kausal ialah studi yang dilakukan dengan tujuan untuk menguji apakah variabel yang satu menyebabkan variabel yang lain berubah atau tidak (Sekaran, 2017: 122). Penelitian ini menguji apakah jumlah zakat produktif, umur produktif, jumlah tanggungan, dan pengawasan berpengaruh terhadap produktivitas usaha.

3. Tingkat Intervensi

Tingkat intervensi terhadap studi penelitian terdiri dari intervensi minimal,intervensi sedang, dan intervensi berlebih. Dalam penelitian ini, peneliti tidak memiliki kemampuan dalam mempengaruhi hubungan antar variabel sehingga penelitian ini menggunakan intervensi minimal.

4. Situasi studi

Situasi studi pada penelitian ini tidak diatur atau biasa disebut dengan studi lapangan. Peneliti ingin mengetahui pengaruh jumlah zakat produktif, umur produktif, jumlah tanggungan dan pengawasan terhadap produktivitas usaha Mustahik di Baitul Mal Kabupaten Pidie.

5. Unit analisis

Unit analisis merujuk pada tingkat kesatuan data yang dikumpulkan selama tahap analisis data (Sekaran, 2017:119). Penelitian ini menggunakan analisis tingkat individu yaitu mustahik yang terdaftar di Baitul Mal di Kabupaten Pidie.

6. Horizon Waktu

Horizon waktu yang digunakan dalam penelitian ini adalah studi cross-sectional. Studi yang dilakukan dengan sekali pengumpulan data, mungkin selama periode hari, minggu, atau bulan, untuk menjawab pertanyaan penelitian (Sekaran, 2017: 122).

\section{Populasi dan Sampel Penelitian}

Sekelompok orang, kejadian atau segala sesuatu yang bisa dipelajari dan ditarik kesimpulannya disebut dengan Populasi (Sekaran, 2006). Populasi dari penelitian ini adalah para mustahik yang terdaftar di Baitul Mal Kabupaten Pidie yang menerima zakat produktif periode 2017 dan 2018, yaitu sebanyak 112 mustahik.

Sampel merupakan bagian kecil dari populasi, yang diambil beberapa representatif dan kemudian diteliti, representatif dari populasi inilah yang dimaksudkan dengan sampel (Kountour, 2004:54). Teknik pengambilan sampel dalam penelitian ini yaitu dengan menggunakan teknik probability sampling (pengambilan sampel secara acak), dengan metode simple random sampling yakni suatu teknik pengambilan sampel anggota populasi secara acak tanpa memperhatikan strata dari populasi tersebut (Notoatmojo, 2010:124).

Penelitian ini menggunakan rumus Slovin untuk penentuan jumlah sampel. Rumus Slovin digunakan untuk menentukan jumlah sampel dari populasi yang jumlahnya sudah diketahui yaitu sebanyak 112 mustahik yang diambil dari data mustahik penerima zakat produktif dari baitul Mal Pidie. Untuk tingkat presiasi yang ditetapkan dalam penentuan sampel adalah $10 \%$ (Kriyantono, 2008:162).

\section{Sumber dan Teknik Pengumpulan Data}

Data dapat diperoleh melalui data pimer maupun sekunder. Dalam penelitian ini data yang digunakan berbentuk sekunder yaitu data yang mengacu pada pengumpulan informasi berdasarkan sumber-sumber yang sudah ada. Pada umumnya data sekunder berbentuk catatan atau dokumentasi perusahaan, publikasi pemerintah, analisis industri yang diberikan oleh internet, web, media, dan lainnya (sekaran, 2017: 130). Dalam penelitian ini data yang digunakan adalah data yang berkaitan dengan data mustahik penerima zakat produktif, yang secara langsung diambil ke kantor Baitul Mal Kabupaten Pidie.

Teknik pengumpulan data yang digunakan dalam penelitian ini berbentuk dokumentasi, dimana pengumpulan data dilakukan dengan cara meminta data yang sebelumnya telah ada. Pengumpulan data dilakukan dengan mengunjungi langsung Baitul Mal 
Kabupaten Pidie dan menanyakan data-data mustahik yang menerima zakat produktif secara langsung.

\section{Definisi Operasionalisasi Variabel Variabel Dependen}

Dalam penelitian ini yang menjadi variabel dependennya adalah produktivitas usaha mustahik. Produktivitas merupakan salah satu faktor utama dalam mendorong pertumbuhan ekonomi dan kehidupan/vatilitas secara optimal. Produktivitas usaha mustahik dalam penelitian ini dihitung berdasarkan output yang dihasilkan mustahik setelah menerima zakat produktif.

\section{Variabel Independen}

Variabel independen (variabel bebas) adalah variabel yang mempengaruhi variabel dependen (varibel terikat), baik secara positif maupun negatif yaitu apabila terdapat variabel independen, variabel dependen juga hadir dalam varibel independen dengan setiap unit kenaikan, terdapat juga penurunan atau kenaikan dalam variabel dependen, yaitu varians yang terdapat dalam variabel dependen ditentukan oleh variabel independen (sekaran, 2017:79).

1. Jumlah Zakat Produktif

Jumlah zakat produktif adalah bantuan modal yang diberikan sebagai tambahan modal usaha dalam jumlah rupiah tertentu. Hal ini dikarenakan salah satu faktor yang menyebabkan seseorang berhenti dari usahanya yaitu karena kurangnya modal. Firdaus (2010) dalam Intyas (2018:130) mengemukakan tipe modal ada dua yaitu : modal sendiri dan modal yang berasal dari luar usaha, seperti pinjaman.

2. Umur Produktif.

Umur produktif merupakan usia dimana mustahik masih sanggup bekerja sehingga bisa menghasilkan sesuatu.

3. Jumlah Tanggungan.

Jumlah tanggungan mustahik adalah keseluruhan anggota keluarga yang biaya hidupnya ditanggung oleh mustahik. Rakhma (2014), menyatakan bahwa jumlah anggota keluarga merupakan keseluruhan anggota keluarga, baik yang tinggal serumah maupun tidak. Besarnya tanggungan keluarga sangat dipengaruhi oleh jumlah anggota keluarga.

4. Pengawasan
Pengawasan merupakan suatu kegiatan yang dilakukan dengan tujuan untuk memastikan apakah pekerjaan tersebut telah dilakukan sesuai dengan rencana semula (Hasanah: 2015).

\section{Metode Analisis \\ Statistik Deskriptif}

Menurut Subagyo (2008:1), Statistik deskriptif adalah bagian dari statistik yang mendalami tentang pengumpulan dan penyajian data, pembuatan diagram atau gambar berkaitan dengan sesuatu, penentuan nilai statistik, dengan cara penyajian data dalam bentuk yang yang lebih mudah dibaca dan dipahami. Objek statistik deskriptif dalam penelitian ini adalah semua variabel dependen dan independen yang digunakan dalam penelitian. Adapun tujuan dari statistik deskriptif adalah untuk menjelaskan keadaan, persoalan atau gejala. Menurut Ghozali (2013:19), Statistik deskriptif memberikan deskripsi atau gambaran suatu data yang dapat dilihat dari varian, standar deviasi, nilai rata-rata (mean), minimum, maksimum, sum, kurtosis, range, dan skewness (Kemencengan distribusi).

\section{Analisis Regresi Linear Berganda}

Regresi merupakan salah satu metode analisis statistik yang berguna untuk mengkaji pengaruh dua variabel atau lebih. Menurut Ghozali (2013:6), Analisis regresi adalah usaha untuk mendeskripsikan dan mengevaluasi hubungan antara variabel independen terhadap variabel dependen, baik satu maupun lebih. Hubungan variabel tersebut berbentuk matematis dan bersifat fungsional. Menurut Ghozali (2013:7), pada Analisis regresi, variabel dibagi menjadi dua bagian, yaitu variabel bergantung (dependent variable) atau variabel respon (response variable) dan variabel explanatory atau penduga (predictor variable) atau variabel bebas (dependent variable). Adapun berdasarkan jenisnya regresi terbagi menjadi beberapa jenis, yaitu regresi sederhana (linear sederhana atau nonlinear sederhana) dan regresi berganda (linear berganda dan nonlinear berganda). Dalam penelitian ini metode yang digunakan adalah analisis linear berganda.

Persamaan regresi dalam penelitian ini dijabarkan sebagai berikut (Sugiono, 2013:277).

$$
\mathrm{Y}=\mathrm{a}+B_{1} X_{1}+B_{2} X_{2}+B_{3} X_{3}+B_{4} X_{4}+\mathrm{e}
$$




\section{Hasil Dan Pembahasan}

\section{Statistik Deskripsi}

Analisis dilakukan sesuai dengan hipotesis yang telah dirumuskan. Data yang diuji meliputi jumlah zakat produktif, umur produktif mustahik, jumlah tanggungan, pengawasan, dan produktivitas usaha mustahik. Tabel 1 berikut memperlihatkan statistik deskriptif dari data penelitian.

Tabel 1

Statistik Deskriptif

\begin{tabular}{|l|c|c|c|c|c|}
\hline & N & Minimu m & Maximu m & Mean & Std. Deviation \\
\hline Jumlah & 53 & 1.00 & 4.00 & 1.6226 & .90355 \\
\hline Umur & 53 & 27.00 & 66.00 & 41.3208 & 8.51192 \\
\hline Tanggungan & 53 & 1.00 & 7.00 & 3.6226 & 1.33339 \\
\hline Pengawasan & 53 & 4.00 & 8.00 & 5.8113 & 1.20984 \\
\hline Produktivitas & 53 & 7.00 & 35.00 & 17.3774 & 6.35557 \\
\hline Valid N (listwise) & 53 & & & & \\
\hline
\end{tabular}

Sumber : Hasil Pengolahan SPSS (2019)

Berdasarkan tabel 1 dapat dilihat produktivitas usaha mustahik (Y) mempunyai nilai minimum 7,00, sedangkan maksimumnya sebesar 35,00. Selanjutnya nilai rata-rata produktivitas mustahik sebesar 17,3774. Variabel ini memiliki nilai standar deviasi 6,35557.

Pada Variabel jumlah zakat produktif (X1) mempunyai nilai minimum 1,00 , sedangkan nilai maksimumnya sebesar 4,00. Selanjutnya untuk nilai rata-rata jumlah zakat produktif sebesar 1,6226, Variabel ini memiliki nilai standar deviasi sebesar 0,90355 .

Variabel umur produktif (X2) mempunyai nilai minimum 27,00, sedangkan nilai maksimumnya sebesar 4,00. Selanjutnya untuk nilai rata-rata jumlah zakat produktif sebesar 41,3208. Variabel ini memiliki nilai standar deviasi sebesar 8,51192.

Variabel Jumlah tanggungan (X3) mempunyai nilai minimum 1,00 , sedangkan nilai maksimumnya sebesar 7,00. Selanjutnya untuk nilai rata-rata jumlah tanggungan sebesar 3,6226. Variabel ini memiliki nilai standar deviasi sebesar 1,33339.

Variabel pengawasan (X4) mempunyai nilai minimum 4,00, sedangkan nilai maksimumnya sebesar

8,00 . Selanjutnya untuk nilai rata-rata jumlah zakat produktif sebesar 5,8113. Variabel ini memiliki nilai standar deviasi sebesar 1,210984.

\section{Hasil Regresi Linear Berganda}

Penelitian ini menggunakan analisis regresi linear berganda untuk menguji pengaruh variabel independen terhadap variabel dependen. Berdasarkan uji hipotesis yang telah dilakukan dengan menggunakan program SPSS (Statisistical Package For Social Science)23, rincian pengaruh masingmasing variabel independen terhadap variabel dependen dapat dilihat pada tabel 2 berikut:

Tabel 2

Pengaruh Variabel Independen terhadap Variabel Dependen

\begin{tabular}{|l|l|l|l|l|l|}
\hline \multirow{2}{*}{ Model } & \multicolumn{2}{|c|}{ Unstandardiz ed Coefficients } & \multicolumn{1}{c|}{$\begin{array}{c}\text { Standard ized } \\
\text { Coeffici ents }\end{array}$} & \multirow{2}{*}{ Sig. } \\
\cline { 2 - 5 } & \multicolumn{1}{|c|}{ B } & \multicolumn{1}{|c|}{ Std. Error } & Beta & & .583 \\
\hline 1 (constant) & 1.981 & 3.583 & & .553 & .000 \\
\hline Jumlah & 6.287 & .567 & .894 & 11.085 & .843 \\
\hline Umur & -.013 & .067 & -.018 & -.200 & .787 \\
\hline Tanggungan & -.119 & .439 & -.025 & -.272 & .018 \\
\hline Pengawasan & 1.064 & .434 & .203 & 2.453 & \\
\hline
\end{tabular}

a. Dependent Variable: Produktivitas

Sumber: Hasil Pengolahan SPSS (2019) 
Berdasarkan hasil perhitungan statistik seperti yang terlihat pada 4.6 maka diperoleh persamaan regresi linear berganda sebagai berikut:

$$
\begin{gathered}
Y=1,981+6,287 X_{1}-0,013 X_{2}-0,119 X_{3}+ \\
1.064 X_{4}+e
\end{gathered}
$$

Persamaan regresi tersebut menghasilkan data yang dapat disimpukan sebagai berikut.

Konstanta (a) sebesar 1,981. Artinya, Jika jumlah zakat produktif, umur produktif mustahik, jumlah tanggungan, dan pengawasan mustahik dianggap konstan, maka besarnya tingkat produktivitas usaha mustahik akan naik sebesar 198,1\%.

\section{Pengujian Hipotesis}

\section{Uji Signifikansi Simultan (Uji Statistik F)}

Pengujian hipotesis uji $\mathrm{F}$ dilakukan untuk melihat pengaruh variabel independen secara keseluruhan terhadap variabel dependen. Pengujian dilakukan dengan membandingkan nilai $\mathrm{F}$ hitung dengan $\mathrm{F}$ tabel atau dengan melihat nilai signifikansi. Hasil pengujian hipotesis uji $\mathrm{F}$ dapat dilihat pada Tabel 3.

Tabel 3

Hasil Uji Statistik F

\begin{tabular}{|l|c|c|c|c|c|}
\hline \multicolumn{1}{|c|}{ Model } & $\begin{array}{c}\text { Sum of } \\
\text { Squares }\end{array}$ & Df & $\begin{array}{c}\text { Mean } \\
\text { Square }\end{array}$ & F & Sig. \\
\hline Regression & 1517.073 & 4 & 379.268 & 31.206 & $.000^{\mathrm{a}}$ \\
\hline Residual & 583.380 & 48 & 12.154 & & \\
\hline Total & 2100.453 & 52 & & & \\
\hline
\end{tabular}

a. Predictors: (Constant), Pengawasan, Umur, Jumlah, Tanggungan b. Dependent Variable: Produktivitas

Sumber: Hasil Pengujian SPSS (2019)

Berdasarkan Tabel 4.7 diperoleh hasil uji signifikansi variabel jumlah zakat produktif, umur produktif mustahik, jumlah tanggungan, dan pengawasan dapat mempengaruhi variabel produktivitas usaha mustahik secara signifikan. Dari uji $\mathrm{F}$ didapat nilai sebesar 31,206 dan signifikansi 0,000. Karena signifikansi lebih kecil dari 0,05 maka dengan demikian, hipotesis pertama yang menyatakan bahwa jumlah zakat produktif, umur produktif mustahik, jumlah tanggungan, dan pengawasan secara bersama-sama berpengaruh terhadap produktivitas usaha mustahik dapat diterima.

\section{Uji Signifikansi Individual (Uji Statistik t)}

Pengujian hipotesis uji $\mathrm{t}$ dilakukan untuk menyelidiki lebih lanjut mana diantara dua variabel bebas yang berpengaruh signifikan terhadap produktivitas. Uji statistik t dilakukan dengan melihat nilai signifikansi yang diperoleh masing-masing variabel.

Berdasarkan tabel 2 menunjukkan hasil pengujian sebagai berikut:

1. Nilai $t$ hitung pada variabel jumlah zakat produktif (X1) adalah sebesar 11,085 dengan signifikansi 0,000 atau signifikansi lebih kecil dari 0,05 menunjukkan bahwa variabel jumlah zakat produktif secara parsial berpengaruh signifikan terhadap produktivitas usaha mustahik, dengan demikian hipotesis kedua dapat diterima. Koefisien regresi jumlah zakat produktif sebesar 6,287 , artinya setiap kenaikan $100 \%$ jumlah zakat produktif akan menaikkan persentase tingkat produktivitas usaha mustahik sebesar $628,7 \%$.

2. Nilai $\mathrm{t}$ hitung pada variabel umur produktif mustahik (X2) adalah sebesar -0,200 dengan signifikansi 0,843 atau signifikansi lebih besar dari 0,05 menunjukkan bahwa variabel umur produktif secara parsial tidak berpengaruh signifikan terhadap produktivitas usaha mustahik, dengan demikian hipotesis ketiga ditolak.

3. Nilai $t$ hitung pada variabel jumlah tanggungan (X3) adalah sebesar -272 dengan signifikansi 0,787 atau signifikansi lebih besar dari 0,05 menunjukkan bahwa variabel jumlah tanggungan mustahik secara parsial tidak berpengaruh signifikan terhadap produktivitas usaha mustahik, dengan demikian hipotesis keempat ditolak.

4. Nilai t hitung pada variabel pengawasan (X4) adalah sebesar 2,453 dengan signifikansi 0,018 atau signifikansi lebih kecil dari 0,05 menunjukkan bahwa variabel pengawasan secara parsial berpengaruh signifikan terhadap produktivitas usaha mustahik, dengan demikian hipotesis kelima dapat diterima. Koefisien regresi pengawasan sebesar 1,064, artinya setiap kenaikan $100 \%$ pengawasan akan menaikkan persentase tingkat produktivitas usaha mustahik sebesar $106,4 \%$ 


\section{Kesimpulan, Keterbatasan dan Saran}

Berdasarkan analisis data dan pembahasan yang telah disajikan sebelumnya mengenai "Pengaruh Jumlah Zakat Produktif, Umur Produktif Mustahik, Jumlah Tanggungan Mustahik, danPengawasan terhadap produktivitas Usaha mustahik (Studi pada Baitul Mal Kabupaten Pidie) maka dapat diambil kesimpulan secarasistematis sebagai berikut.

1) Jumlah zakat produktif, umur produktif mustahik, tanggungan dan pengawasan secara simultan berpengaruh signifikan terhadap produktivitas usaha mustahikdi Baitul Mal Kabupaten Pidie.

2) Jumlah zakat produktif berpengaruh signifikan terhadap produktivitas usaha mustahik. Hal ini berarti zakat produktif yang diberikan kepada mustahik bermanfaat bagi mustahik sehinggamempengaruhi produktivitas mustahik.

3) Umur Produktif mustahik tidak berpengaruh terhadap produktivitas usaha mustahik. Hal ini semuda apapun umur mustahik tidak berdampak pada produktivitas usaha mustahik

4) Tanggungan mustahik tidak berpengaruh terhadap Produktivitas usaha mustahik. Hal ini berarti sebanyak apapun jumlah tanggungan mustahik tidak berdampak pada produktivitas usaha mustahik

5) Pengawasan berpengaruh terhadap produktivitas usaha mustahik. Hal ini berarti bahwa pengawasan bermanfaat bagi mustahik sehingga mempengaruhi produktivitas usaha mereka

\section{Keterbatasan Penelitian}

Penelitian ini objeknya yaitu mustahik yang memperoleh zakat produktif yang berasal dari Baitul Mal Pidie, belum mewakili seluruh Aceh, sehingga terdapat kemungkinan perbedaan hasil penelitian jika objeknya lebih luas.

\section{Saran Akademis}

Peneliti selanjutnya diharapkan untuk menambahkan variabel-variabel lain yang merupakan faktor-faktor yang dapat mempengaruhi produktivitas usaha.

\section{Saran Praktis}

Bagi Baitul Mal diharapkan dapat meningkatkan pendistribusian zakat produktif kepada mustahik yang membutuhkan, dikarenakan hasil dari penelitian menunjukkan bahwa zakat produktif dapat membantu untuk meningkatkan produktivitas usaha mustahik. Bagi Mustahik yang menerima zakat produktif diharapkan dapat mempergunakan zakat produktif tersebut dengan sebaik mungkin sehingga dapat meningkatkan kualitas serta kuantitas dari usaha yang dikelolanya.

\section{Daftar Pustaka}

Afrida, BR. 2003. Ekonomi Sumber Daya Manusia. Jakarta: Ghalia Indonesia.

Asnainu. 2008. Zakat Produktif dalam Perspektif Islam. Bengkulu: Pustaka Pelajar.

Busro, Muhammad. 2018. Teori-teori Manajemen Sumber Daya Manusia. Jakarta: Prenadamedia Grup

Fajrin, Stevani Fitra Osika. 2015. Pengaruh Dana Zakat Produktif terhadap Keuntungan Usaha Mikro Mustahiq (Studi Kasus Laz El-Zawa Uin 3 Maliki Malang). Jurnal Ilmiah Universitas Brawijaya Vol 3, No. 2.

Fitriani, Widya Francisca \& Priantina, Anita. 2016. Analisis Penguraian Masalah pada Program Zakah Produktif.Jurnal Al-Muzara'ah Vol. 4, No. 2, 2016

Ghozali, Imam. 2013. Aplikasi Analisis Multivariat dengan Program IBM SPSS 21. Edisi 7. Semarang: Penerbit Universitas Diponegoro.

Harsanto, Budi. 2013. Dasar Ilmu Manajemen Operasi. Bandung: Unpad Press

Hasanah, Siti Nur. 2015. Strategi Pengawasan Program Pendayagunaan Zakat Produktif Menuju Kesejahteraan Masyarakat (Studi Kasus Kab. Semarang)

Himawan, Wanda Ekki. 2015. Analisis Faktor-faktor yang Mempengaruhi Produktivitas Tenaga Kerja pada KUD Sumberrejo Unit SKT (Sigaret Kretek Tangan) Sukorejo Studi Kasus pada Bagian Pengelinting Rokok KUD Sumberrojo Unit SKT Sukorejo. Jurnal Ilmiah Mahasiswa FEB Universitas Brawijaya Vol.4, No.1 https://m.detik.com,. Diakses pada 25 Maret 2019 Intyas, adi Candi \& Zainal Abidin. 2018. Manajemen Agribisnis Perikanan. Malang: UB Press

Kountur, R. 2004. Metode Penelitian untuk Penelitian Skripsi dan Tesis. Jakarta: PPM. 
Kriyantono R. 2008. Teknik Praktis Riset Komunikasi. Jakarta: Kencana Prenada.

Lestari., et al.2009. Sistem Pendukung Keputusan Pengukuran dan Analisis Produktivitas Usaha Kecil Dan Menengah Menggunakan Metode Objective Matrix Studi Kasus: Dinas Perindustrian dan Perdagangan Kabupaten Bangkalan. Jurnal Ilmiah KURSOR Vol. 5, No. 2:129-136.

ModusAceh.co. Diakses pada 25 Maret 2019

Muda, Iskandar \& Arfan, Muhammad. 2016. Pengaruh Jumlah Zakat Produktif, Umur Produktif Mustahik, dan Lama Usaha Mustahik Terhadap Produktivitas Usaha Mustahik (Studi Pada Baitul Mal Kota Banda Aceh). Jurnal Ilmiah Mahasiswa Ekonomi Akuntansi, 1(1), 318-326.

Notoatmodjo, Soekidjo. 2010. Metodologi Penelitian Kesehatan. Jakarta: Rineka Cipta.

Pambudi, Hidayat Aji. 2013. Peranan Zakat Produktif dalam Pemberdayaan Masyarakat Miskin (Studi Kasus pada Badan Amil Zakat (BAZ) Kabupaten Kebumen. Tanpa Volume. Diakses melalui via http://journal.stieputrabangsa.ac.id

Qardawi , Yusuf. 2011. Hukum Zakat. Bogor: Pustaka Litera Antar Nusa.

Rakhma, Annisa Nur \& Marlina Ekawaty . 2014. Analisis Faktor-faktor yang Mempengaruhi Kesejahteraan Mustahik Penerima ZIS Produktif (Studi pada Lagzis Baitul Ummah Malang). Jurnal Ilmu Ekonomi FEB Universitas Brawijaya.

Rusli. 2013. Analisis Dampak Pemberian Modal Zakat Produktif terhadap Pengentasan Kemiskinan di Kabupaten Aceh Utara. Jurnal Ilmu Ekonomi Pascasarjana Universitas Syiah Kuala, Vol 1, No 1:56-63.

Salmawati \& Fitri, Meutia. 2018. Pengaruh Tingkat Pendapatan, Religiusitas, Akuntabilitas dan Kualitas Pelayanan terhadap Minat Muzakki Membayar Zakat di Baitul Mal Kota Banda Aceh. Jurnal Ilmiah Mahasiswa Ekonomi Akuntansi, vol. 3, No. 1.

Sekaran, Uma. 2006. Reseach Methods for Business. Edisi Keempat. Jakarta: Salemba Empat.

Simanjuntak. 1998. Pengantar Ekonomi Sumber
Daya Manusia. Jakarta: Lembaga Penerbit Fakultas Ekonomi UI.

Sinungan, Muchdarsyah. 2003. Produktivitas apa dan Bagaimana. Jakarta: Bumi Aksara.

Soetrisno, Edy. 2009. Manajemen Sumber Daya Manusia. Jakarta:Kencana.

Subagyo, Pagestu. 2008. Statistik Deskriptif. Yogyakarta: BPFE.

Sugiono. 2013. Metodelogi Penelitian Kuantitatif, Kualitatif dan $R \& D$. Bandung:ALFABETA.

Sunaengsih, Cucun., et al., 2017. Pengelolaan Pendidikan. Sumedang: UPI Sumedang Press 